\title{
Picoplankton abundance and biomass across the eastern South Pacific Ocean along latitude $32.5^{\circ} \mathrm{S}$
}

\author{
Carolina Grob $^{1,2, *}$, Osvaldo Ulloa ${ }^{2}$, William K. W. Li ${ }^{3}$, Gadiel Alarcón ${ }^{2}$, \\ Masao Fukasawa ${ }^{4}$, Shuichi Watanabe ${ }^{4}$ \\ ${ }^{1}$ Graduate Programme in Oceanography, and ${ }^{2}$ Department of Oceanography \& Center for Oceanographic Research in the \\ Eastern South Pacific, University of Concepcion, Casilla 160-C, Concepcion, Chile \\ ${ }^{3}$ Biological Oceanography Section, Bedford Institute of Oceanography, Dartmouth, Nova Scotia B2Y4A2, Canada \\ ${ }^{4}$ Mutsu Institute of Oceanography, Japan Agency for Marine-Earth Science and Technology, 2-15 Natsushima, Yokosuka, \\ Kanagawa 237-0061, Japan
}

\begin{abstract}
The distribution of picoplankton $(<2$ to $3 \mu \mathrm{m}$ in diameter $)$ was determined on a transect across the eastern South Pacific Ocean from south of Tahiti to the coast of Chile along $32.5^{\circ} \mathrm{S}$ latitude during the early austral spring. The abundance of Synechococcus, picophytoeukaryotes and bacterioplankton increased from oligo- to eutrophic conditions, while that of Prochlorococcus decreased according to nutrient availability and hydrographic characteristics. Bacterioplankton dominated across the transect (>75\% total picoplanktonic abundance). As expected, Prochlorococcus was the most numerically abundant phytoplankter under very oligotrophic (chlorophyll a concentration $\leq 0.1 \mathrm{mg} \mathrm{m}^{-3}$ ) and mesotrophic $\left(>0.1\right.$ and $\leq 1 \mathrm{mg} \mathrm{m}^{-3}$ ) conditions. However, in contrast to other subtropical regions, picophytoeukaryotes appear to dominate the $<2 \mu \mathrm{m}$ autotrophic carbon biomass in this region of the South Pacific Ocean at this time of the year. In the upper $200 \mathrm{~m}$ of the water column, the integrated carbon biomass of Prochlorococcus, Synechococcus, picophytoeukaryotes and bacterioplankton were in the ratios of 9:1:14:11 and 3:1:8:6 under oligo- and mesotrophic conditions, respectively. Thus, picophytoeukaryotes were 1.4- to 2-fold higher in biomass than both cyanobacteria combined, and slightly more important (1.2- to 1.3-fold) than bacterioplankton. Picophytoeukaryotes could therefore play a dominant ecological and biogeochemical role in subtropical gyres, which extend over a vast area of the world's oceans.
\end{abstract}

KEY WORDS: Picophytoeukaryotes ' Bacterioplankton · Carbon biomass · Cyanobacteria · Flow cytometry

Resale or republication not permitted without written consent of the publisher

\section{INTRODUCTION}

Marine picophytoplankton $(<2$ to $3 \mu \mathrm{m}$ in diameter $)$ play a very important role in the planktonic community, especially in oligo- and mesotrophic regions of the ocean where they make a large contribution to carbon production, biomass and energy transfer (Stockner 1988). Picoplankton includes cyanobacteria of the genera Synechococcus (Waterbury et al. 1979) and Prochlorococcus (Chisholm et al. 1988), eukaryotes of diverse taxa (e.g. Moon-van der Staay et al. 2001) and bacterioplankton, which include both Bacteria and Archaea (Giovan- noni \& Rappé 2000) that do not carry out oxygenic photosynthesis. Bacterioplankton abundance and chlorophyll a ( $\mathrm{chl}$ a) concentration are linearly related across different aquatic ecosystems (Gasol \& Duarte 2000), through a positive or negative slope, indicating a bottomup or top-down control on bacteria, respectively (Li et al. 2004). Such interactions between autotrophic and heterotrophic picoplanktonic organisms strongly influence the fate of biogenic carbon in the open ocean. It is therefore important to characterise this small size fraction of the microbial plankton under different oceanographic, biogeochemical and trophic conditions. 


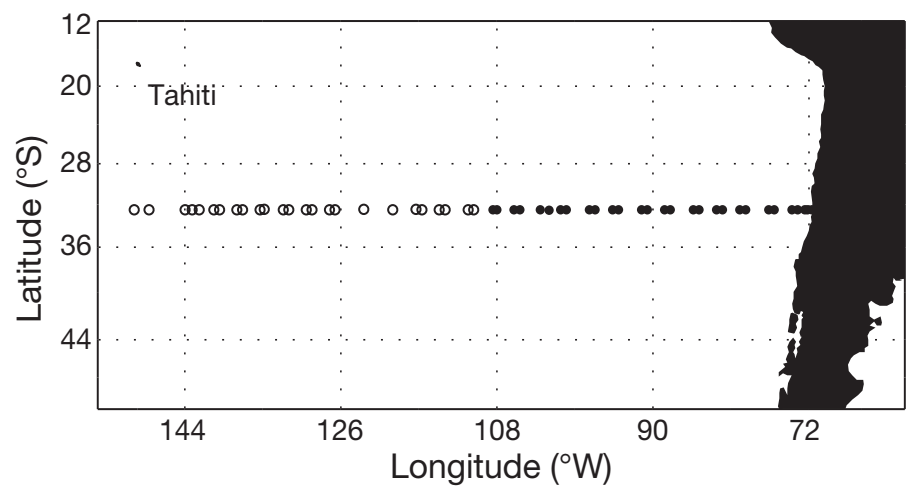

Fig. 1. Stations sampled in the eastern South Pacific at the surface only (O) and at the surface and 10, 50, 100, 150 and $200 \mathrm{~m}(\bullet)$

In the oligotrophic waters studied to date, Prochlorococcus and bacterioplankton usually dominate the microbial plankton both in terms of numbers and mass (e.g. Zubkov et al. 2000). Along trophic gradients, Prochlorococcus abundance shows opposite patterns to Synechococcus and picophytoeukaryotes abundance, becoming a less important component of the carbon standing stock from oligo- to eutrophic conditions (e.g. Partensky et al. 1996, Zubkov et al. 2000). However, because of high cellular carbon and chl a content, picophytoeukaryotes can nevertheless contain more biomass than the prokaryotes, even when greatly outnumbered. For instance, in the Arabian Sea the largest eukaryotic phytoplankton cells with higher carbon content were preferentially found in the poorest oceanic waters (Shalapyonok et al. 2001). Satellite images of ocean colour show that the South Pacific subtropical gyre is extremely oligotrophic. This is a large region in which the contribution of picophytoeukaryotes has not been well characterised. Since most $(\sim 90 \%)$ of the ocean is under oligo- or mesotrophic conditions, the influence of picophytoeukaryotes would have significant impact on the marine primary production, the cycling of bioelements and the ecology of the global ocean.

In this work we present the first detailed picoplankton data set available for the eastern South Pacific Ocean, extending from very oligotrophic to highly productive conditions. We used flow cytometry to: (1) determine the abundance and distribution of Prochlorococcus, Synechococcus, picophytoeukaryotes and bacterioplankton; (2) analyse the variability in community structure in relation to the trophic conditions and hydrographic characteristics; and (3) determine the contribution of each group to the total picoplanktonic carbon biomass. Our results highlight the importance of picophytoeukaryotes in these oligotrophic waters.

\section{MATERIALS AND METHODS}

The study was carried out in the eastern South Pacific Ocean along latitude $32.5^{\circ} \mathrm{S}$ during the second track (Leg 2) of the Japanese BEAGLE (Blue Earth Global Expedition, Japan Agency for Marine-Earth Science and Technology [JAMSTEC]; Uchida \& Fukasawa 2005) cruise, between September 12, and October 12, 2003 (austral spring time). Samples for flow cytometric analyses were taken from surface waters at 25 stations between south of Tahiti $\left(\sim 149.5^{\circ} \mathrm{W}\right)$ and Easter Island $\left(\sim 109^{\circ} \mathrm{W}\right)$. Between this island and the coast of Chile $\left(\sim 71.5^{\circ} \mathrm{W}\right)$, we sampled multiple depths (surface, 10, 50, 100, 150, $200 \mathrm{~m}$ ) at 29 stations (Fig. 1). Surface samples (Tahiti to Chile) were taken either from CTD casts (i.e. 1 to $3 \mathrm{~m}$ ), the ship's flow system (i.e. 3 to $5 \mathrm{~m}$ ), or with a bucket (i.e. $0 \mathrm{~m}$ ). All samples (surface and water column) were fixed with paraformaldehyde (1\% final concentration) and quickfrozen in liquid nitrogen. For bacterioplankton counts, samples were stained with SYBR Green I (Molecular Probes). Cytometric analyses for both picophytoplankton and bacterioplankton were performed with a FACSCalibur (Becton Dickinson) flow cytometer according to Marie et al. $(2000 \mathrm{a}, \mathrm{b})$. The contribution of high DNA (HDNA)- and low DNA (LDNA)-containing bacteria to total bacterioplankton abundance was estimated according to Li et al. (1995), as a proxy for active and inactive cells, respectively (Gasol et al. 1999). Cell Quest Pro and Cytowin software were used for data acquisition and analysis, respectively. Picoplanktonic populations were differentiated based on their scattering and fluorescence signals (Marie et al. 2000a,b). When surface Prochlorococcus populations were not well defined because of their weak fluorescence, their abundance was determined by fitting a Gaussian curve to the data using the Cytowin software. Forward scatter (FSC) and chl a fluorescence (FL3) cytometric signals were normalised to reference beads (Fluoresbrite YG Microspheres, calibration grade $1.00 \mu \mathrm{m}$, Polysciences) and expressed in relative units (r.u.) to be used as indicators of mean cell size and photoacclimation, respectively (e.g. Campbell \& Vaulot 1993).

Prochlorococcus, Synechococcus and picophytoeukaryotes abundances were integrated over the water column ( 0 to $200 \mathrm{~m}$ ) to determine the contribution of each group to the total number of picophytoplanktonic cells. For calculating water-columnintegrated picoplanktonic carbon biomass (IPCB), conversion factors of 53 and $100 \mathrm{fg} \mathrm{C} \mathrm{Cell}^{-1}$ were chosen from the literature as the most representative and conservative values for Prochlorococcus and Synechococcus, respectively (see Table 1). For open ocean (i.e. oligo- and mesotrophic conditions) and coastal (i.e. eutrophic conditions) picophytoeukaryotes, we used 
Table 1. Conversion factors from the literature for Prochlorococcus (Proc), Synechococcus (Syn), picophytoeukaryotes (Euk) and bacterioplankton (Bact) carbon biomass (in $\mathrm{fg} \mathrm{C}_{\mathrm{C}} \mathrm{cell}^{-1}$ )

\begin{tabular}{|lcccl|}
\hline Proc & Syn & Euk & Bact & Reference \\
\hline $17-124$ & - & - & - & Bertilsson et al. (2003) and references therein \\
32 & 101 & $\sim 750-1833$ & - & Shalapyonok et al. (2001) \\
29 & 100 & 1500 & 12 & Zubkov et al. (2000) \\
39 & 82 & 530 & - & Worden et al. (2004) \\
53 & 250 & - & - & e.g. Partensky et al. (1996), Campbell et al. (1994) \\
- & 250 & - & $16 \& 20$ & Fuhrman et al. (1989) \\
- & - & - & 27 & Troncoso et al. (2003) \\
- & - & & $12-30$ & Fukuda et al. (1998) \\
\hline
\end{tabular}

1500 and $530 \mathrm{fg} \mathrm{C}^{\mathrm{C}}$ cell $^{-1}$, respectively, because mean FSC signals (i.e. relative cell size) were significantly lower in the latter than the former populations. The use of the same conversion factor for the whole water column and transect for Synechococcus and with depth for the picophytoeukaryotes is justified by the fact that no statistically significant differences were found between mean FSC signals (analyses of variance, p < 0.001 for both depth and trophic conditions). Although such differences were indeed significant for Prochlorococcus with depth, the use of different conversion factors for the surface and deep populations did not lead to significant differences in the integrated biomass $(\mathrm{p}<$ 0.001, data not shown). Bacterioplankton biomass was calculated using 12 and $27 \mathrm{fg} \mathrm{C} \mathrm{Cell}^{-1}$ for the open ocean and coastal samples, respectively (see Table 1).

Temperature, salinity and oxygen profiles were obtained with a conductivity-temperature-depthoxygen profiler (CTDO, Seabird 911 Plus). Nitrate, nitrite, phosphate and silicate concentrations were determined onboard using an autoanalyser and standard techniques. Nutrient concentrations near instrumental detection limit were approximated to 0 . Total chl $a$ and phaeopigment concentrations were measured fluorometrically (Turner Design, Model 10AU005CE) for all but 1 of the stations. The missing profile was obtained by triangle-based interpolation. Since no surface hydrographic data were collected, we assumed homogeneous conditions in the top layer and used the $10 \mathrm{~m}$ hydrogaphic values as surface values.

To interpret cytometric abundances in relation to the physical and biogeochemical conditions of the water column, we only used data above the depth of $0.1 \%$ of surface light intensity, since below this level picophytoplankton growth and therefore distribution should be mostly limited by light. Using Eqs. (3a) and (1b) in Morel \& Berthon (1989), we first calculated the euphotic zone depth for each profile $\left(Z_{\mathrm{e}}\right.$, corresponding to $1 \%$ of surface light intensity) and then the attenuation coefficients $(k)$ using the light attenuation equation (Kirk 1994). For Eq. (3a), we used our surface chl a concentrations as their $C_{\text {sat }}$, assuming that it roughly corresponds to what would be measured from satellites. Knowing $k$ for every station, we then determined the $0.1 \%$ value of surface light intensity by using the light attenuation equation one more time. To examine vertical changes in normalised cytometric size and fluorescence signals, we computed the optical depth $(k z)$ as $k$ times $z$ for each profile, where $z$ is the actual sampling depth and $k$ is the diffuse attenuation coefficient estimated for each station.

According to surface chl a concentrations $\left(\mathrm{mg} \mathrm{m}^{-3}\right)$, we discuss our results in terms of oligo- $(\leq 0.1)$, meso$(>0.1$ and $\leq 1)$ and eutrophic $(>1)$ conditions (Antoine et al. 1996). Although this division does not directly take into account the nutrient concentrations, it has been used to characterise the trophic status of the ocean from space and, hence, can be used to place our results in a global bio-optical context.

\section{RESULTS}

\section{Picoplankton abundance and community structure}

Flow cytometric analyses allowed us to determine the abundance of the cyanobacteria Prochlorococcus and Synechococcus, and of picophytoeukaryotes and bacterioplankton. A marked increase in FSC and FL3 with the optical depth $(k z>4.6)$ indicates that a more fluorescent Prochlorococcus population consisting of larger sized cells replaces a less fluorescent surface population of smaller cells with depth (Fig. 2). A similar pattern was observed for picophytoeukaryotes, although no statistically significant differences were found between the mean FSCs of surface and deep populations $(\mathrm{p}<0.001)$. On the other hand, Synechococcus mean relative cell size was relatively constant with depth, although their mean fluorescence showed a slight increase towards intermediate depths. It is worth noting that below $k z=12(<0.01 \%$ of surface light) the FSC and FL3 signals of all 3 groups are more dispersed because of the very low cell abundance (Fig. 2). 


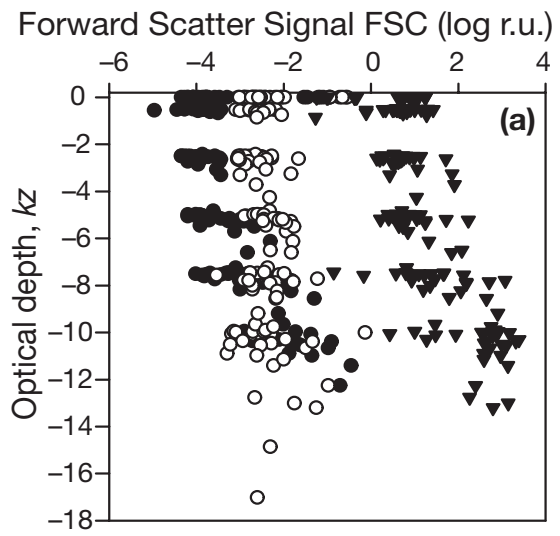

Chl a Fluorescence Signal (log r.u.)

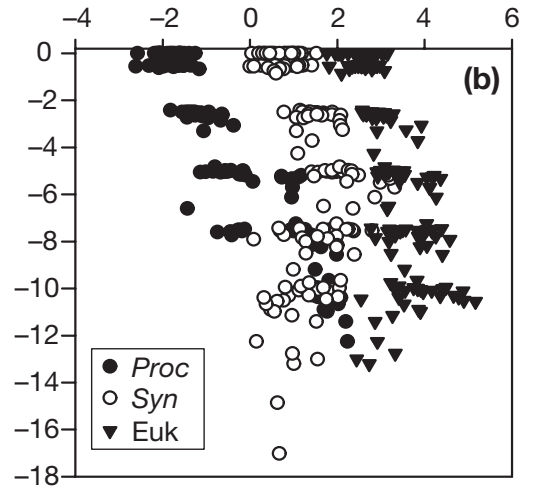

Fig. 2. Forward scatter signal (FSC) (a) and chl a fluorescence signal (b) variability with optical depth (kz, dimensionless) forProchlorococcus (Proc, $\bullet$ ), Synechococcus $($ Syn, O) and picophytoeukaryotes (Euk, $\mathbf{\nabla}) ; k$ : diffuse attenuation coefficient estimated for each station; $z$ : actual sampling depth; r.u. = relative units

With the exception of Prochlorococcus, which decreased from the mesotrophic region towards the coast, the abundance of all other cells, as well as the chl a concentration, increased from oligo- to eutrophic conditions (Fig. 3, Table 2). Mean $( \pm \mathrm{SD})$ surface $(10 \mathrm{~m})$ nitrogen (nitrate + nitrite), phosphate and silicate concentrations under oligotrophic conditions were $0.51 \pm 0.51,0.22 \pm 0.04$ and $0.41 \pm 0.28 \mu \mathrm{mol} \mathrm{kg}^{-1}$, respectively. Under meso- and eutrophic conditions nitrogen increased to $1.76 \pm 2.30$ and $10.06 \pm 2.33 \mu \mathrm{mol}$ $\mathrm{kg}^{-1}$, respectively, while phosphate and silicate reached $0.44 \pm 0.26$ and $0.35 \pm 0.18 \mu \mathrm{mol} \mathrm{kg} \mathrm{kg}^{-1}$ in the former and $1.39 \pm 0.37$ and $3.34 \pm 2.75 \mu \mathrm{mol} \mathrm{kg}^{-1}$ in the latter region, respectively. Maxima Prochlorococcus, Synechococcus, picophytoeukaryotes and bacterioplankton concentrations were found in the top $50 \mathrm{~m}$ of the mesotrophic region (up to $\sim 25,4,2$ and $140 \times 10^{4}$ cells $\mathrm{ml}^{-1}$, respectively) and very close to the Chilean coast for the last 3 groups (up to $\sim 3,2$ and $127 \times 10^{4}$ cells $\mathrm{ml}^{-1}$, respectively). Picophytoeukaryotes maxima were associated with a deep chlorophyll maximum (DCM) and the highest chlorophyll concentrations ( $\sim 2$ to $5 \mathrm{mg} \mathrm{m}^{-3}$ ), respectively (Fig. 3). Water-columnintegrated abundance was dominated by bacterioplankton along the whole transect (Table 2). Of the 3 picophytoplanktonic groups, only Prochlorococcus integrated abundance was significantly correlated to the mixed-layer depth $\left(Z_{\mathrm{m}}\right)$ estimated by Bouman et al. (2006). Mean integrated chl a concentration increased from oligo- $\left(17 \pm 2 \mathrm{mg} \mathrm{m}^{-2}\right)$ to mesotrophic conditions $\left(26 \pm 9 \mathrm{mg} \mathrm{m}^{-2}\right)$ and was highest under eutrophic conditions $\left(212 \pm 98 \mathrm{mg} \mathrm{m}^{-2}\right)$. HDNA bacterioplankton represented on average $45 \pm 4,47 \pm 5$ and $48 \pm 10 \%$ of total counts under oligo-, meso- and eutrophic conditions, respectively. Their contribution in the open ocean (i.e. oligo- and mesotrophic) was slightly higher above $100 \mathrm{~m}$ (3 to $5 \%$ ) than below this depth.
Integrated bacterioplankton abundance (surface to $0.1 \%$ of surface light) was positively and significantly correlated to both Synechococcus and picophytoeukaryotes, these 2 picophytoplanktonic groups being strongly correlated to each other (Table 3). Prochlorococcus integrated abundance, on the other hand, was not significantly correlated to any of the other groups (Table 3). The relationship between total bacterioplankton abundance and chl a concentration observed along the transect (data not shown) lies within the macroecological limits established for the open ocean (Li et al. 2004), and a clear positive slope was observed for chlorophyll concentrations $\leq 0.2 \mathrm{mg} \mathrm{m}^{-3}\left(\mathrm{R}^{2}=0.66\right.$, $\mathrm{p}<0.0001)$. Mean water-column-integrated chl a concentrations ( 0 to $200 \mathrm{~m}$ ) were $\sim 17,26$ and $212 \mathrm{mg} \mathrm{m}^{-2}$ in the oligo-, meso- and eutrophic regions, respectively.

Prochlorococcus abundance was positively related with water temperature $\left(\mathrm{R}^{2}=0.54, \mathrm{p}<0.0001\right)$, and negatively, with inorganic nitrogen (i.e. nitrate + nitrite, $\left.\mathrm{R}^{2}=0.53, \mathrm{p}<0.0001\right)$, phosphate $\left(\mathrm{R}^{2}=0.51, \mathrm{p}<\right.$ $0.0001)$ and silicate concentrations $\left(R^{2}=0.33, p<\right.$ $0.0001)$, temperature being negatively correlated to all nutrients and salinity ( $\mathrm{p}<0.001)$. No statistically significant relationships with these variables were found for Synechococcus or the picophytoeukaryotes, except for a very weak negative one between the former and temperature $\left(\mathrm{R}^{2}=0.03, \mathrm{p}<0.05\right.$, data not shown). All 3 groups' abundances exhibited a negative relationship with salinity $\left(\mathrm{R}^{2} \geq 0.3, \mathrm{p}<0.0001\right)$.

\section{Picoplanktonic carbon biomass}

West of Easter Island, mean surface bacterioplankton and Prochlorococcus carbon biomasses were equivalent (2.9 $\mathrm{mg} \mathrm{C} \mathrm{m}^{-3}$ in both cases) and higher than those of Synechococcus $\left(0.1 \mathrm{mg} \mathrm{C} \mathrm{m}^{-3}\right)$ and the pi- 


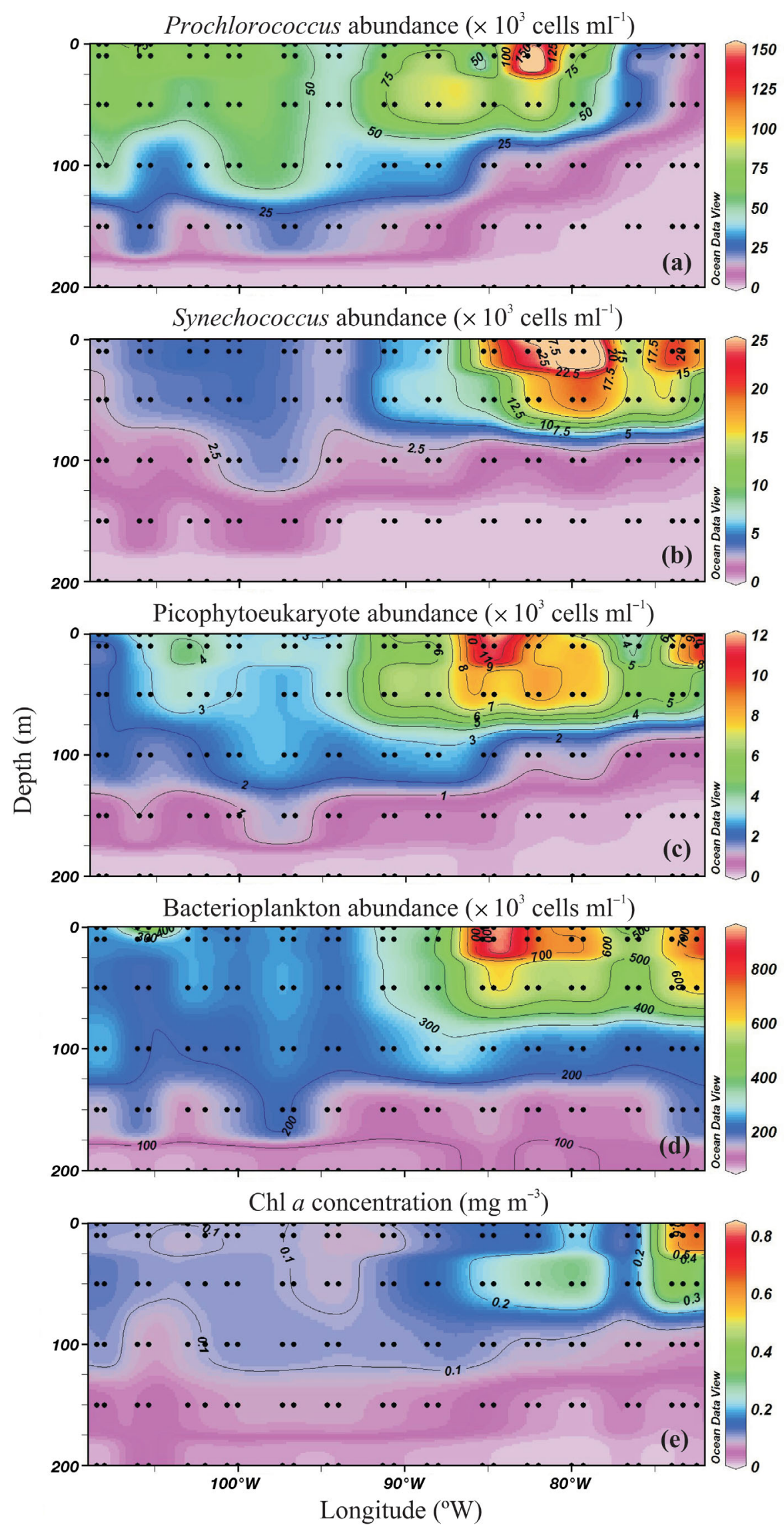

Fig. 3. Water column Prochlorococcus (a), Synechococcus (b), picophytoeukaryotes (c) and bacterio-plankton abundances (d) in cells $\mathrm{ml}^{-1}$, and chl a concentrations (e) in $\mathrm{ml} \mathrm{m}^{-3}\left(\sim 32.5^{\circ} \mathrm{S}, \sim 109\right.$ to $\left.72.5^{\circ} \mathrm{W}\right)$ 
Table 2. Mean ( \pm SD) water-column-integrated (0 to $200 \mathrm{~m})$ Prochlorococcus, Synechococcus, picophytoeukaryotes and bacterioplankton abundance $\left(\times 10^{11}\right.$ cells $\left.\mathrm{m}^{-2}\right)$ along $32.5^{\circ} \mathrm{S}$, between Easter Island and the coast of Chile. The transect range includes the minimum and maximum values found along the transect (when present in the case of Prochlorococcus). Campbell \& Vaulot (1993) ranges are indicated for comparison. Transect range and Campbell \& Vaulot (1993) results for picophytoeukaryotes are presented in bold and italic to highlight the differences observed between them

\begin{tabular}{|lccccc|}
\hline Group & Oligotrophic & Mesotrophic & Eutrophic & Transect range & $\begin{array}{c}\text { Global range published by } \\
\text { Campbell \& Vaulot (1993) }\end{array}$ \\
\hline Prochlorococcus & $76 \pm 15$ & $62 \pm 45$ & 0 & $5-122$ & $7-200$ \\
Synechococcus & $4 \pm 1$ & $12 \pm 6$ & $9 \pm 2$ & $2-23$ & $1-20$ \\
Picophytoeukaryotes & $4 \pm 1$ & $6 \pm 2$ & $6 \pm 2$ & $\mathbf{2 - 1 1}$ & $\mathbf{0 . 2 - 4}$ \\
Bacterioplankton & $395 \pm 44$ & $651 \pm 145$ & $919 \pm 58$ & $332-1016$ & - \\
\hline
\end{tabular}

Table 3. Correlation matrix for picoplankton integrated abundances (surface to $0.1 \%$ of surface light) (upper right values: correlation coefficients; ${ }^{* * *} \mathrm{p}<0.0001$; ns: not statistically significant)

\begin{tabular}{|lcccc|}
\hline & Prochlorococcus & Synechococcus & Picophytoeukaryotes & Bacterioplankton \\
\hline Prochlorococcus & 1.00 & $\mathrm{~ns}$ & $\mathrm{~ns}$ & $\mathrm{~ns}$ \\
Synechococcus & - & 1.00 & $0.714^{* * *}$ & $0.854^{* * *}$ \\
Picophytoeukaryotes & - & - & 1.00 & $0.715^{* * *}$ \\
Bacterioplankton & - & - & - & 1.00 \\
\hline
\end{tabular}

cophytoeukaryotes $\left(1.5 \mathrm{mg} \mathrm{C} \mathrm{m}^{-3}\right.$ ). East of Easter Island, where we were able to sample through the upper water column ( 109 to $72.5^{\circ} \mathrm{W}, 0$ to $200 \mathrm{~m}$, IPCB), picophytoeukaryotes had the highest integrated biomass in most of the oligotrophic and part of the mesotrophic region, but bacterioplankton had higher biomass in the rest of the transect (Fig. 4, Table 4). Prochlorococcus and bacterioplankton integrated biomass decreased and increased from oligo- to eutrophic conditions, re- spectively. Synechococcus and picophytoeukaryotes integrated biomass, on the other hand, increased from oligo- to meso- and decreased slightly from meso- to eutrophic conditions (Fig. 4). Similar to bacterioplankton abundance, total picoplanktonic carbon biomass (i.e. Prochlorococcus + Synechococcus + picophytoeukaryotes + bacterioplankton carbon biomass at each sampled point) was positively correlated to chl a concentrations $\leq 0.2 \mathrm{mg} \mathrm{m}^{-3}\left(\mathrm{R}^{2}=0.77, \mathrm{p}<0.0001\right)$.

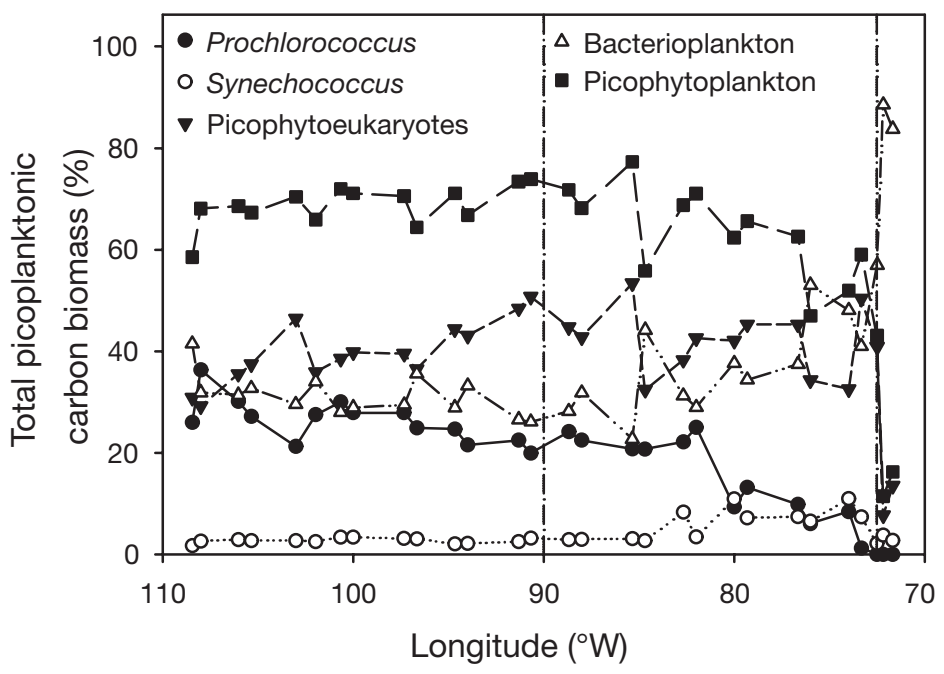

Fig. 4. Prochlorococcus (๑), Synechococcus (0), picophytoeukaryotes $(\mathbf{\nabla})$, bacterioplankton $(\Delta)$ and picophytoplankton (Prochlorococcus + Synechococcus + picophytoeukaryotes, - contribution to watercolumn-integrated picoplanktonic carbon biomass. vertical lines indicate limits between oligo- and mesotrophic conditions $\left(90^{\circ} \mathrm{W}\right)$ and between meso- and eutrophic conditions $\left(72.5^{\circ} \mathrm{W}\right)$

\section{DISCUSSION}

The South Pacific subtropical gyre is by far the most unexplored region of the world's ocean. Until now, virtually the only information concerning phytoplankton at the centre of this gyre was surface chl a concentrations estimated through satellite images, whereas bacterioplankton abundance remained completely unknown. The BEAGLE results show some general features typically observed in other oligo-, meso- and eutrophic regions during similar periods of the year, but differ significantly in the more oligotrophic conditions encountered along the transect. Here, the relative biomass composition of the picoplankton community comprising Prochlorococcus, Synechococcus, picophytoeukaryotes and bacterioplankton was different from other studies of subtropical gyres. Instead of Prochlorococcus, it was the picophytoeukaryotes 
that dominated the carbon biomass together with the bacterioplankton.

The distribution patterns of picoplanktonic abundance observed across the eastern South Pacific subtropical gyre reflect changes in trophic conditions, nutrient availability and water column stability (Partensky et al. 1996, Zubkov et al. 2000, Shalapyonok et al. 2001, Worden et al. 2004). However, in the oligotrophic region, Prochlorococcus abundance was 1 order of magnitude lower than the range established for them elsewhere ( 1 to $4 \times 10^{5}$ cells ml $^{-1}$; Partensky et al. 1999) and about half of the values reported for the North and South Atlantic subtropical gyres during spring time (Zubkov et al. 2000). Synechococccus abundance was 1 order of magnitude lower and those of picophytoeukaryotes and bacterioplankton similar to the ones reported by Zubkov et al. (2000). However, Synechococcus abundance was within the range reported by Partensky et al. (1999) for central gyres. Near the coast Synechococcus abundance values were similar to those reported for other upwelling areas, but picophytoeukaryotes abundance was found to be twice the highest reported value (Sherr et al. 2005 and references therein). It is important to highlight that watercolumn-integrated picophytoplankton abundances observed along the transect were within the global estimates published by Campbell \& Vaulot (1993) for both cyanobacteria, but surprisingly higher for picophytoeukayotes (Table 2).

Although the use of linear regressions in microbial ecology has limitations (discussed elsewhere, e.g. Duarte et al. 2000a), our results agree with previous observations on the influence of temperature (e.g. Partensky et al. 1996) and macronutrient availability (e.g. Bertilsson et al. 2003) on the distribution of Prochlorococcus. The strong positive correlations between Synechococcus and picophytoeukaryotes abundance may be explained by similar nitrogen utilisation abilities (Worden et al. 2004) and growth stimulation towards the coast, provided by the less stable water column and shallower nutricline that allows injection of nutrients to the surface (Partensky et al.
1996, Shalapyonok et al. 2001). The lack of relationships with nutrient concentration does not necessarily contradict the latter, but rather indicates that other factors (e.g. grazing and virus lysis) may be controlling the abundances of these 2 groups as well. The fact that no significant correlations were found between the mixed-layer depth $\left(Z_{\mathrm{m}}\right)$ and the integrated abundances of Synechococcus and picophytoeukaryotes (0 to $200 \mathrm{~m}$ or 0 to $Z_{\mathrm{m}}$ ) further indicates this possibility (data not shown). Different time responses of these 2 groups to the addition of nutrients, as observed in mesocosm experiments (Duarte et al. 2000b) and in Norwegian coastal waters (Larsen et al. 2004), could also explain our observations. Limitation by nutrients other than nitrogen, phosphate and silicate cannot be rejected, since, for example, iron has been shown to increase Prochlorococcus growth rates (Mann \& Chisholm 2000), but appears to have no influence on those of Synechococcus or picophytoeukaryotes (Timmermans et al. 2005).

Negative relationships between all 4 picoplanktonic group abundances and salinity, such as the ones found here, have already been observed along a marked salinity gradient for salinities >23.5 (Joshem 2003). Synechococcus and picophytoeukaryotes correlations with the bacterioplankton abundance, which is known to covary with phytoplankton biomass, were expected, since all 3 groups tend to increase with nutrient supply (Gasol \& Duarte 2000). Higher bacterioplankton abundance in the upwelling area off Chile compared with, for instance, the Mauritarian upwelling region (Zubkov et al. 2000) can be explained by the high productivity levels of the former region (Stuart et al. 2004).

HDNA bacterioplankton is thought to be related to the metabolically active part of the bacterial community (Gasol et al. 1999). However, Sherr et al. (2006) found that when phytoplankton biomass is low, HDNA bacterioplankton represented only a fraction of this active part. Considering the above, our results indicate then a lower limit for active bacterioplankton, averaging $50 \%$ (ranging from $\sim 33$ to $58 \%$ ) of the total abundance, which is close to mean HDNA contributions registered elsewhere (Gasol et al. 1999). Although the spatial variability in percent HDNA (increasing from oligo- to eutrophic conditions and with depth) followed the same patterns observed in the North Atlantic, Mediterranean and Northeast Pacific Ocean (Li et al. 1995, Gasol et al. 1999, Sherr et al. 2006), the range of contribution to total bacterioplankton abundance in the eastern South Pacific was usually lower and their dominance was less evident. 
Different light-adaptation capabilities allow Prochlorococcus and picophytoeukaryotes to distribute deeper than Synechococcus in the water column (e.g. Partensky et al. 1996, 1999). Increasing fluorescence signals with optical depth (Fig. 2b) may be attributed to: (1) an increase in the synthesis of chl a at lower light levels associated with photoacclimation processes or (2) the presence of different picophytoplanktonic ecotypes. The former has been observed in all 3 groups (e.g. Partensky et al. 1996), is usually less pronounced for picophytoeukaryotes than for cyanobacteria (e.g. Campbell \& Vaulot 1993) and could be producing the DCM observed in the eastern mesotrophic region (Fig. 3c,e), although the presence of nanophytoplanktonic cells, not considered here, cannot be ruled out. A clear example of the latter is the presence of 2 Prochlorococcus populations observed here (Fig. 2a) and also described for other oligotrophic regions (Campbell \& Vaulot 1993, Partensky et al. 1996, Zubkov et al. 2000). Using molecular probes, highlight- and low-light-adapted Prochlorococcus ecotypes were found to co-dominate in the surface waters of the South Pacific subtropical gyre (Bouman et al. 2006). However, because samples for the detection of ecotypes were collected only at the sea surface, we were unable to determine if the higher fluorescence below the mixed layer and euphotic depths was caused by a shift towards a dominance of low-light ecotypes. Although different Synechococcus (e.g. Rocap et al. 2002) and picophytoeukaryotes (e.g. Rodríguez et al. 2005) ecotypes have also been observed in natural samples, flow cytometry data alone do not allow us to identify them or determine their physiological or genetic microdiversity.

Higher chl a concentrations near the Chilean coast are mainly due to the presence of larger phytoplankton cells, such as diatoms, that dominate the phytoplanktonic community in upwelling systems (Stuart et al. 2004) and that are usually underestimated by flow cytometry (e.g. Shalapyonok et al. 2001). The positive relationship between chl a concentrations $\leq 0.2 \mathrm{mg} \mathrm{m}^{-3}$ and bacterial abundance would indicate a bottom-up control on this group in the oligo- and part of the mesotrophic regions, as inferred from macroecological patterns (Li et al. 2004). Towards the coast this relationship would be lost due to the presence of larger cells, or due to a stronger response from autotrophs than from heterotrophs to greater nutrient availability (Duarte et al. 2000a). This would also explain the relationship found with the total picoplanktonic carbon biomass.

In terms of carbon biomass, the picture is quite different from what has been observed in other oligo- and mesotrophic regions of the world's ocean during the same period of the year. The picophytoeukaryotes, instead of Prochlorococcus or Synechococcus (e.g.
Partensky et al. 1996, Zubkov et al. 2000, see Table 1 for conversion factors), dominated the autotrophic biomass along the whole transect, their dominance in the upwelling region being expected (Worden et al. 2004, Sherr et al. 2005 and references therein). Picophytoeukaryotes also co-dominated the IPCB with bacterioplankton along most of the transect (Fig. 4). The latter differs from the results of Fuhrman et al. (1989) for the oligotrophic Sargasso Sea, where the microbial carbon biomass (i.e. bacterioplankton + auto- and heterotrophic nanoflagellates + cyanobacteria) was dominated by the bacterioplankton. Using lower Prochlorococcus or Synechococcus conversion factors would not modify our conclusions regarding the relative importance of bacterioplankton and picophytoeukaryotes carbon biomass. If, for example, the conversion factor for picophytoeukaryotes was changed to $750 \mathrm{fg} \mathrm{C}^{\mathrm{C}} \mathrm{cll}^{-1}$ (i.e. half of what we used), this group's mean contribution to IPCB in the oligo- and mesotrophic regions ( 25 and $27 \%$, respectively) would be lower than that of bacterioplankton ( 39 and $48 \%$, respectively), but only slightly below that of Prochlorococcus in the former $(\sim 33 \%)$ and higher in the later $(\sim 18 \%)$ region. Total picophytoplanktonic carbon biomass would still be higher than that of bacterioplankton under both oligotrophic $(\sim 61 \%)$ and $(\sim 52 \%)$ mesotrophic conditions. In the eutrophic zone picophytoeukaryotes would represent about one-sixth of the bacterioplankton carbon biomass, but would still be 5 times more important than that of Synechococcus. It is worth noting that if this lower conversion factor for picophytoeukaryotes was obtained through the relationship pg $\mathrm{C}=0.433 \times$ (biovolume) $^{0.866}$ (Campbell et al. 1994 and references therein), their mean cell size would have to be of $1.54 \mu \mathrm{m}$, which is rather conservative. These considerations support a view of the importance of the picophytoeukaryotic carbon stock under the different trophic conditions encountered along the transect during spring time.

Under oligotrophic conditions, mean integrated carbon biomass proportions between Prochlorococcus, Synechococcus, picophytoeukaryotes and bacterioplankton were $\sim 9: 1: 14: 11$, respectively. These proportions changed to $\sim 3: 1: 8: 6$ and $\sim 0: 1: 9: 26$ in the meso- and eutrophic regions, respectively. This gives bacterioplankton to picophytoplankton carbon biomass ratios of $0.46,0.5$ and 2.6 for the oligo-, meso- and eutrophic regions, respectively. Ratios $<1$ for bacterioplankton to phytoplankton integrated carbon biomass have been reported as a general feature for different ecological provinces in the North Atlantic Ocean (Li \& Harrison 2001), with values $\geq 1$ at low chl a concentrations, where picophytoplankton dominates. Considering the above, the higher ratios observed in the mesoand eutrophic regions of the South Pacific subtropical 
gyre can then be attributed to the presence of phytoplanktonic cells $>3 \mu \mathrm{m}$ that we did not consider in our analyses. Low ratios, on the other hand, do not necessarily imply that autotrophs are dominant, since heterotrophic organisms other than bacterioplankton need to be taken into account. Indeed, Gasol et al. (1997) have shown that in open-ocean systems of low primary productivity, the ratio of total heterotrophic biomass (i.e. bacteria, protists and mesozooplankton) to total autotrophic biomass is very high. Because of the very oligotrophic conditions encountered in the eastern South Pacific, it is likely that eukaryotic heterotrophic organisms would significantly contribute to the total integrated heterotrophic biomass.

Carbon flow towards higher trophic levels would be more efficient and would tend to escape remineralisation when the picophytoeukaryotes dominate the picophytoplanktonic biomass. Until now, the scenario was that of an open ocean dominated by cyanobacteria, in which an extremely efficient microbial loop would remineralise most of the organic matter produced (Azam 1998). Although very little is known about picophytoeukaryotes, this group would be far more diverse than cyanobacteria (e.g. Moon-van der Staay et al. 2001), which could possibly explain their success in the open ocean. A shift in dominance from cyanobacteria to picophytoeukaryotes such as the one observed during early spring in the eastern South Pacific could imply a shift in the dominant biogeochemical pathways that directly affect carbon fate in the ocean. Despite the fact that our results represent only a snap shot of the situation in the eastern South Pacific, they highlight the importance of the picophytoeukaryotes carbon biomass under trophic conditions where cyanobacteria were expected to dominate all year (e.g. Partensky et al. 1996, Zubkov et al. 2000). Because of their potential influence on the carbon flow, the importance of this group at the annual scale could be significant, even if the observed situation was to be true only for the relatively short sampling period.

In the oligo- and mesotrophic regions of the eastern South Pacific, we have found the carbon biomass of picophytoplankton to be higher than that of bacterioplankton during spring time. However, it will require studies of metabolic processes to place this finding in the perspective of global biogeochemical cycles, especially regarding carbon cycling, and in the global climate system. Production (i.e. primary and secondary) and loss rate (e.g. grazing and virus lysis) measurements, as well as genetic assays and temporal surveys need to be incorporated into a more comprehensive study. The eastern South Pacific Ocean deserves further attention, and the extremely oligotrophic centre of this subtropical gyre ( $~ 0.01 \mathrm{mg} \mathrm{m}^{-3}$; Claustre \& Maritorena 2003) needs to be included in future studies of global processes.
Acknowledgements. We thank the captain and crew of the RV 'Mirai' and 'Michio Oayama' (GRD/MRI) for the nutrient data. Data collection was facilitated by scholarships provided by POGO and IOCCG and IOC to participants from Chile, Peru and Turkey on Leg 2 of the BEAGLE Expedition. We are also grateful to V. Molina, H. Bouman, G. Yuras, R. Wiff, L. A. Cuevas, V. Stuart, S. Sathyendranath and T. Platt for help and support. This work was funded by the Chilean National Commission for Scientific and Technological Research (CONICYT) through the Funds for Advanced Research in Priority Areas (FONDAP) Programme. Additional support was provided by Fundación Andes and the Japan Agency for Marine-Earth Science and Technology. C.G. was supported by a CONICYT graduate fellowship.

\section{LITERATURE CITED}

Antoine D, André JM, Morel A (1996) Oceanic primary production. II. Estimation at global scale from satellite (Coastal Zone Color Scanner) chlorophyll. Global Biogeochem Cycles 10:57-69

Azam F (1998) Microbial control of oceanic carbon flux: the plot thickens. Science 280:694-696

Bertilsson S, Berglund O, Karl DM, Chisholm SW (2003) Elemental composition of marine Prochlorococcus and Synechococcus: implications for the ecological stoichiometry of the sea. Limnol Oceanogr 48:1721-1731

Bouman HA, Ulloa O, Scanlan D, Zwirglmaier K and 10 others (2006) Oceanographic basis of the global surface distribution of Prochlorococcus ecotypes. Science 312: 918-921

Campbell L, Vaulot D (1993) Photosynthetic picoplankton community structure in the subtropical North Pacific Ocean near Hawaii (Station ALOHA). Deep-Sea Res I 40: 2043-2060

Campbell L, Nolla HA, Vaulot D (1994) The importance of Prochlorococcus to community structure in the central North Pacific Ocean. Limnol Oceanogr 39:954-961

Chisholm SW, Olson RJ, Zettler ER, Goericke R, Waterbury JB, Welschmeyer NA (1988) A novel free-living prochlorophyte occurs at high cell concentrations in the oceanic euphotic zone. Nature 334:340-343

Claustre H, Maritorena S (2003) The many shades of ocean blue. Science 302:1514-1515

Duarte CM, Agustí S, Gasol JM, Vaqué D, VazquezDominguez E (2000a) Effect of nutrient supply on the biomass structure of planktonic communities: an experimental test on a Mediterranean coastal community. Mar Ecol Prog Ser 206:87-95

Duarte CM, Agustí S, Agawin NSR (2000b) Response of a Mediterranean phytoplankton community to increased nutrient inputs: a mesocosm experiment. Mar Ecol Prog Ser 195:61-70

Fuhrman JA, Sleeter TD, Carlson CA, Proctor LM (1989) Dominance of bacterial biomass in the Sargasso Sea and its ecological implications. Mar Ecol Prog Ser 57:207-217

Fukuda R, Ogawa H, Nagata T, Koike I (1998) Direct determination of carbon and nitrogen contents of natural bacterial assemblages in marine environments. Appl Environ Microb 64:3352-3358

Gasol JM, Duarte CM (2000) Comparative analyses in aquatic microbial ecology: How far do they go? FEMS Microbiol Ecol 31:99-106

Gasol JM, del Giorgio PA, Duarte CM (1997) Biomass distribution in marine planktonic communities. Limnol Oceanogr 42:1353-1363 
Gasol JM, Zweifel UL, Peters F, Fuhrman JA, Hagström A (1999) Significance of size and nucleic acid content heterogeneity as measured by flow cytometry in natural planktonic bacteria. Appl Environ Microb 65:4475-4483

Giovannoni S, Rappé M (2000) Evolution, diversity, and molecular ecology of marine prokaryotes. In: Kirchman DL (ed) Microbial ecology of the oceans. Wiley-Liss, New York, p 47-84

Joshem FJ (2003) Photo- and heterotrophic pico- and nanoplankton in the Mississippi River plume: distribution and grazing activity. J Plankton Res 25:1201-1214

Kirk J (1994) Light and photosynthesis in aquatic ecosystems, 2nd edn. Cambridge University Press, New York

Larsen A, Flaten GAF, Sandaa RA, Castberg T, Thyrhaug R, Erga SR, Jacquet S, Bratbak G (2004) Spring phytoplankton bloom dynamics in Norwegian coastal waters: microbial community succession and diversity. Limnol Oceanogr 49:180-190

Li WKW, Harrison WG (2001) Chlorophyll, bacteria and picophytoplankton in ecological provinces of the North Atlantic. Deep-Sea Res II 48:2271-2293

Li WKW, Jellett JF, Dickie PM (1995) DNA distributions in planktonic bacteria stained with TOTO or TO-PRO. Limnol Oceanogr 40:1485-1495

Li WKW, Head EJH, Harrison WG (2004) Macroecological limits of heterotrophic bacterial abundance in the ocean. Deep-Sea Res I 51:1529-1540

Mann EL, Chisholm SW (2000) Iron limits the cell division rate of Prochlorococcus in the eastern equatorial Pacific. Limnol Oceanogr 45:1067-1076

Marie D, Partensky F, Simon N, Guillou L, Vaulot D (2000a) Flow cytometry analysis of marine picoplankton. In: Diamond RA, DeMaggio S (eds) In living colors: protocols in flow cytometry and cell sorting. Springer-Verlag, New York, p 421-454

Marie D, Simon N, Guillou L, Partensky F, Vaulot D (2000b) DNA, RNA analysis of phytoplankton by flow cytometry. In: Robinson JP, Darzynkiewicz Z, Dean PN, Orfao A, Rabinovitch PS, Stewart CC, Tanke HJ, Wheeless LL (eds) Current protocols in cytometry, Suppl 11, Unit 11.12. John Wiley \& Sons, New York, p 1-16

Moon-van der Staay SY, Wachter RD, Vaulot D (2001) Oceanic 18S rDNA sequences from picoplankton reveal unsuspected eukaryotic diversity. Nature 409:607-610

Morel A, Berthon JF (1989) Surface pigments, algal biomass profiles, and potential production of the euphotic layer: relationships reinvestigated in view of remote-sensing applications. Limnol Oceanogr 34:1545-1562

Partensky F, Blanchot J, Lantoine F, Neveux J, Marie D (1996) Vertical structure of picophytoplankton at different trophic sites of tropical northeastern Atlantic Ocean. Deep-Sea Res I 43:1191-1213

Editorial responsibility: Otto Kinne (Editor-in-Chief), Oldendorf/Luhe, Germany
Partensky F, Blanchot J, Vaulot D (1999) Differential distribution and ecology of Prochlorococcus and Synechococcus in oceanic waters: a review. Bull Inst Oceanogr Monaco 19:457-475

Rocap G, Distel DL, Waterbury JB, Chisholm SW (2002) Resolution of Prochlorococcus and Synechococcus ecotypes by using $16 \mathrm{~S}-23 \mathrm{~S}$ ribosomal DNA internal transcribed spacer sequences. Appl Environ Microb 68:1180-1191

Rodríguez F, Derelle E, Guillou L, Gall FL, Vaulot D, Moreau $\mathrm{H}$ (2005) Ecotype diversity in the marine picoeukaryote Ostreococcus (Chlorophyta, Prasinophyceae). Environ Microbiol 7:853-859

Shalapyonok A, Olson RJ, Shalapyonok LS (2001) Arabian Sea phytoplankton during southwest and northeast monsoons 1995: composition, size structure and biomass from individual cell properties measured by flow cytometry. Deep-Sea Res II 48:1231-1261

Sherr EB, Sherr BF, Wheeler PA (2005) Distribution of coccoid cyanobacteria and small eukaryotic phytoplankton in the upwelling ecosystem off the Oregon coast during 2001 and 2002. Deep-Sea Res II 52:317-330

Sherr EB, Sherr BF, Longnecker K (2006) Distribution of bacterial abundance and cell-specific nucleic acid content in the Northeast Pacific Ocean. Deep-Sea Res I 53:713-725

Stockner JG (1988) Phototrophic picoplankton: an overview from marine and freshwater ecosystems. Limnol Oceanogr 33:765-775

Stuart V, Ulloa O, Alarcón G, Sathyendranath S, Major H, Head EJH, Platt T (2004) Bio-optical characteristics of phytoplankton populations in the upwelling system off the coast of Chile. Rev Chil Hist Nat 77:87-105

Timmermans KR, van der Wagt B, Veldhuis MJW, Maatman A, de Baar HJW (2005) Physiological responses of three species of marine pico-phytoplankton to ammonium, phosphate, iron and light limitation. J Sea Res 53:109-120

Troncoso VA, Daneri G, Cuevas LA, Jacob B, Montero P (2003) Bacterial carbon flow in the Humboldt Current System off Chile. Mar Ecol Prog Ser 250:1-12

Uchida H, Fukasawa M (2005) WHP P6, A10, I3/I4 Revisited data book, Blue Earth Global Expedition 2003 (BEAGLE 2003) Vols 1 and 2. JAMSTEC, Yokosuka, Kanagawa

Waterbury JB, Watson SW, Guillard RRL, Brand LE (1979) Widespread occurrence of a unicellular, marine planktonic, cyanobacterium. Nature 277:293-294

Worden AZ, Nolan JK, Palenik B (2004) Assessing the dynamics and ecology of marine picophytoplankton: the importance of the eukaryotic component. Limnol Oceanogr 49: 168-179

Zubkov MV, Sleigh MA, Burkill PH, Leakey RJG (2000) Picoplankton community structure on the Atlantic Meridional Transect: a comparison between seasons. Prog Oceanogr 45:369-386

Submitted: November 3, 2005; Accepted: July 24, 2006 Proofs received from author(s): February 20, 2007 